\title{
Microfinance and Women Empowerment: A Panel Data Analysis Using Evidence from Rural Bangladesh
}

\author{
Ms. Sarahat Salma Chowdhury (Corresponding Author) \\ Lecturer, Department of Business Administration, East West University \\ 49 Mohakhali C/A, Dhaka 1212, Bangladesh \\ Tel: 88-017-1303-3292Ｅ-mail: sarahat.chowdhury@gmail.com
}

\author{
Ms. Sifat Adiya Chowdhury \\ Lecturer, Department of Economics, North South University \\ Bashundhara, Dhaka 1229, Bangladesh
}

Tel: 88-017-1291-8728Ｅ-mail: sifat.adi@gmail.com

Received: February 26, 2011

Accepted: March 7, 2011

doi:10.5539/ijef.v3n5p86

\begin{abstract}
Microfinance has long been associated with generating empowerment of women. Over $90 \%$ of their clients in Bangladesh are women. The rising demand for credit may seem to indicate the popularity of the program. However, analysing why demand for credit is rising among women may offer a way to analyse empowerment of women. Therefore, this paper utilises this fact and uses a panel data survey to measure individual level outcomes such as labour supply, asset accumulation and family planning and household level outcomes such as children education and household expenditure per annum from participating in a credit program. These outcomes would then be compared to outcomes that can be achieved from borrowing loans from a non-program source. By comparing these outcomes, the benefit of micro finance is extracted, which in turn, is further analysed in terms of whether they indicate empowerment of women.
\end{abstract}

Keywords: Fixed Effect Model, Micro Credit, Women Empowerment

\section{Introduction}

Ever since microfinance was initiated in Bangladesh in the mid-1970s, not only has it offered credit to support self-employment and small business creation in rural Bangladesh but also established an environment that has led to improve the economic and social status of women. This is underpinned by the unprecedented growth of microfinance through female borrowers. Grameen Bank is a case in point. When it started its micro-credit operation in mid 1980s, 65\% of its borrowers were female. By 1995, they represented 95\% of all borrowers of microfinance (Khandker et al, 1995). This expansion through women is also noticeable among other NGOs that provide micro-credit, such as BRAC (Bangladesh Rural Advancement Committee), ASA (Association for Social Advancement) and PROSHIKA. This is surprising considering the 'purdah' society that prevails in Bangladesh. Women are taught to stay at home, refrain from expressing their opinions and seek permission from men regarding any financial or household decisions they take. Defying the men can lead to, amongst others, domestic violence. However, offering credit to the men rather than the women carry the risk of the money being wasted by being spent on gambling, alcohol and tobacco (Armendáriz and Roome, 2008). Hence, greater credit provisions in the society through women can generate much needed social and economic benefits to the credit receiving women. A low drop-out rate and high loan recovery rate (over 90\%) also support the trend of targeting women since they are crucial for sustaining micro-credit programs (Khandker et al, 1995). Having studied the reasons for which microfinance mainly targets women, it is important to know what benefits accrue to these participating women. This essay will attempt to throw new light on the topic of microfinance and women empowerment by examining micro credit's various effects on empowering women in rural Bangladesh.

The rest of the essay is structured as follows: Section 2 builds on the literature review, detailing work done previously on possible association between micro-credit and women empowerment. Section 3 explains the objective of this paper. Section 4 explains the data and research methodology that are utilised in this paper, Section 5 reports the findings of this paper along with the analysis and Section 6 concludes, referring to fields to work on in future. 


\section{Literature Review}

Empowerment is a broad field to analyze and there is no general consensus on the definition of "women empowerment'. While the United Nations guidelines on women empowerment set out five components defining empowerment (women's sense of self-worth; their right to have and to determine choices; their right to have access to opportunities and resources; their right to have the power to control their own lives, both within and outside the home; and their ability to influence the direction of social change to create a more just social and economic order, nationally and internationally), common belief defines empowerment of women as the ability to make self-decisions, freedom to participate in activities of their choice and accessing resources available both within and outside their homes. Writing about whether the availability of micro-credit empowers women in rural Bangladesh is by no means unique. Various articles have been written in the past, and there is no general consensus on whether micro credit empowers the women who receives the credit. Hashemi et al, 1996, found that participation in credit programs increases women's mobility, their ability to make purchases and major household decisions, their ownership of productive assets, their legal and political awareness and participation in public campaigns and protests. Another study of Grameen Bank concluded that female participants in credit programs are more conscious of their rights, better able to resolve conflicts and have more control over decision making at household and community levels (Chen, 1996). However, this view is not universal. Goetze et al (1996) has concluded in spite of receiving credit, women empowerment had a long way to come. In reaching this conclusion Goetze et al emphasis that the Bangladeshi society are still having backdated beliefs about the roles of women and that in order to empower women through micro-credit, mentalities need to change.

There had also been several workings on differentiating impacts of microfinance by gender. Most notable of them is Pitt and Khandker's (1998) study whereby they reported that marginal impact of microfinance on consumption was $18 \%$ for women compared to $11 \%$ of men. They also reported women's loans (from Grameen Bank) had a positive statistical effect on girls' schooling in the household compared to men's loans. The findings were concluded to be a result of lack of fungibility of credit borrowed by men within the household. However, Morduch (1998) rejected the positive impacts found by Pitt $\&$ Khandker claiming there were no reported increases in consumption levels or school enrolment of children of the borrowers relative to the non-borrowers in microfinance villages. In particular, he raised questions on validity of models used and assumptions made by Pitt \& Khandker. Nevertheless, Pitt (1999) further explained the workings of 1998's paper and verified Morduch's misunderstanding on their work.

Most relevant work for this paper is the panel data analysis done by Khandker (2005). Using the same household survey as Pitt \& Khandker (1998) but creating a panel with it, the author computed dynamic effects of microfinance by gender. It reported significant positive dynamic impacts on women (thus proving the benefits found in Pitt \& Khandker's paper to be sustainable in future, albeit at a decreasing rate) in terms of greater household expenditure. It is Khandker's $(2005,2008)$ fixed effects model that is established in this paper to evaluate individual level impacts of micro credit and their underlying references towards empowerment.

\section{Objectives of the Study}

The objectives of this paper are as follows:

Analyse any empowerment effects that microfinance can generate through impacts on an individual level such as labour supply, fertility and asset accumulation as well as household level outcomes such as expenditure and schooling of children.

Compare the outcomes of obtaining micro credit from microfinance institutions only for the eligible participants to the outcomes of credit borrowed from other sources (except credit from microfinance institutions) by eligible nonparticipants (Note 1).

\section{Research Methodology}

This paper will be applying a panel data analysis on empowerment (Note 2).Using panel data for micro-credit analysis is advantageous because it enables to evaluate if results are sustainable in future and also makes provision for time lags involved in outcomes being experienced from program participation (Note 3 ). The paper measures both individual level outcomes using an individual-level fixed-effects model and household outcomes using a household-level fixed-effects model. These models were selected because individual level outcomes such as labour supply, asset accumulation and family planning were recorded for both men and women in dataset. Therefore, it is more appropriate to employ an individual-level fixed-effects model for these measurements since any unobservable heterogeneity that vary across individuals and also influence demand and outcome effects can be captured by the model (Note 4). For similar reason, in the context of household, household expenditure and children's schooling are measured using a household-level fixed-effects model.

\subsection{Data Description}

This paper will be using data from the Bangladesh Institute of Development Studies-World Bank's Credit Programs for the Poor 1991/92 survey and its follow-up survey in 1998/99. A panel data is formed by combining the two cross 
sectional data of 1991/92 and 1998/99. There were a total of 1633 households who were interviewed in both time periods. It is worth mentioning that the surveys are quasi-experimental in nature where both target households (eligible households) and "non-target households" (not eligible households) had been sampled from both program and non-program villages and eligible participants and eligible non-participants were sampled from eligible households in program villages" (Khandker 2005).

Table 1 reports the distribution of panel households by participation. From Table 1, it can be noticed that there is an increase in number of eligible household participants and decrease in number of eligible non-participating households (a decrease of almost 65\%). Analysing the reasons for not participating in 1991/92, it was revealed that $90 \%$ of target non participants in 1991/92 did not participate in credit programmes either due to reluctance to join or due to lack of economic opportunities This phenomenon proves not only the rapid expansion of microfinance programs in rural Bangladesh but also indirectly hints towards the gaining popularity among individuals who seek cheap credit.

\subsection{Indicators of Empowerment Used}

Selecting specific outcomes of microfinance was done bearing in mind the cultural background and societal norms from which rural Bangladeshi women come and also what results would define their empowerment, i.e. an indication towards greater economic freedom, both inside and outside their homes. The following outcomes have been reported in this paper since they can make way for greater economic status, self-dependency and more likely to improve bargaining power within the household.

\subsubsection{Labour Supply:}

This has been measured in terms of number of days worked in the last 30 days in agricultural sector and non-agricultural sector. Labour supply can represent one of the indicators of freedom to participate outside home for women. Therefore, if women who are borrowing loans from microfinance are observed to be participating more in the labour market, that may indicate an empowering effect.

4.2.2 Non-Land Asset Accumulation:

Various assets fall under this category: bicycles, agricultural animals such as cows and poultry, utensils, electronic goods and gold/silver ornaments. By accumulating assets, a woman becomes more financially self-dependent, is better able to manage finances and most importantly, it can give her some power over decision-making within the household. Thus, there seem to be improvements in social status and position within the household for the woman through asset accumulation. Therefore, if micro-credit borrowers exhibit positive non-land asset accumulation, this may indicate empowerment (Note 5).

4.2.3 Family Planning:

Being able to plan for family is a crucial determinant of women empowerment. If women are more able to communicate with their husbands and persuade them regarding number of children to have, it can indicate women having better household status. However, this indicator needs to be interpreted carefully. Fewer additional births may not necessarily arise due to greater social awareness and family planning advice obtained through microfinance institutions. It may arise if husbands decide not to have many children or if there is some crisis experienced that resulted in loss of income stream and therefore the household decided to have fewer children. Furthermore, the GoB (Government of Bangladesh) has also been promoting family planning methods across the country which may affect the decisions of micro credit borrowers. However, applying the similarity assumption between eligible participants and eligible non-participants prior to program placement decisions, this paper will assume that all eligible women (participants and non-participants) are the landless poor with little or no education. Often these backgrounds can lead to excessive births. Hence, fewer additional births can indicate better family planning methods and greater empowerment of women in these households.

\subsubsection{Children's Education}

This is a household level decision which could also represent women empowerment. The outcome measured in this paper is number of children aged 5-12 years who are enrolled in school (Note 6). Women are mainly responsible for looking after household members. As such, their first port of investment of the micro credit received is more likely to be on household members and for the household as a whole (e.g. expenditure on household goods). This may indirectly reflect an empowering effect because by contributing to household expenditure, they may gain the support of other non-household-head members. This may enable the women to gradually gain independence in making their own choices, thereby promoting empowerment.

4.2.5 Household Expenditure Per Annum

Once again this is a household level decision which may not necessarily indicate empowerment since the dataset does not reveal who is making the expenditure decisions. However, this measurement is included to support the claim that female micro credit borrowers spend more in household expenditure relative to other non-micro credit 
borrowers. This paper will thus prove there are intra-household benefits of borrowing by women which, overtime, can bring them the support from family members and eventually lead to independence over self-decision making. The following quote obtained from Hashemi et al (1996) proves this:

'In the past my father-in-law would never stop my husband from beating me. But after I joined Grameen Bank he said to my husband, "You had better stop beating and scolding your wife. Now she has contact with many people in society. She brings you loans from Grameen Bank. If you want to you can start a business with the money she brings!"

\subsection{Econometric Specification and Concerns:}

Measuring impacts of microfinance to analyse women's empowerment incorporates certain problems. Capturing program participation of eligible participants can incorporate biases occurring from program placement and self-selection. Since among the women who were eligible to participate some opted for participating in the program while some chose not to participate, there is a self-selection issue involved. Perhaps those who self-selected themselves to participate have greater entrepreneurial skills or better innate abilities than non-participants. This could generate upward biases in our estimates which in turn may exaggerate empowerment effects on women. Similarly, microfinance institutions tend to select villages in a non-random manner, often placing themselves in villages which are economically deprived. As such, impacts of microfinance can be downward biased since we would measure outcomes in a poor economically performing region (Pitt and Khandker, 1998). The heterogeneity across individuals and at the village level that can influence program participation and program placement needs to be addressed in setting up the model for this paper.

Fixed-effects (FE) model assumes the time-invariant variables are correlated with other observable variables for individuals and households. For the outcomes measured in this paper, this is applicable (e.g. unobserved innate ability of individuals can depend on education, age, if working and so on). In addition, FE assumes these unobservable individual, household and village characteristics remain constant over time. Therefore, it gets rid of the unobservable characteristics that remain constant overtime and eliminates possibility of endogeneity bias arising. Furthermore, if attrition bias (Note 7) is caused by the time-invariant household/individual characteristics, fixed-effects model can eliminate the bias (Khandker 2005).

The paper will firstly calculate program participation of eligible participants by measuring the demand for credit. The following equation represents log of cumulative borrowed money (reflecting demand for credit) for woman i in village $\mathrm{v}$ at time $\mathrm{t}$ :

$$
M_{i v t}=\alpha X_{i v t}+\beta_{i v}+\gamma_{v}+\varepsilon_{i v t}
$$

where $M_{i v t}$ is demand for credit for individual i in village $\mathrm{v}$ at time t, $X_{i v t}$ is a vector of observable variables used to control for individual, village and household characteristics, $\beta_{i v}$ represents the unobservable individual characteristic that is fixed over time, $\gamma_{v}$ is the unobservable village characteristics fixed over time, $\alpha, \beta$ and $\gamma$ are parameters to be estimated and $\varepsilon_{i v t}$ is the idiosyncratic error term. The fitted value from this equation is then included in the outcome equation of woman $\mathrm{i}$ in village $\mathrm{v}$ at time $\mathrm{t}$ :

$$
Y_{i v t}=\theta X_{i v t}+\sigma X_{i v(t-1)}+\omega M_{i v t}+\rho M_{i v(t-1)}+\mu_{i v}+\varphi_{v}+u_{i v t}
$$

where $Y_{i v t}$ measures the outcome due to participation in the program, $M_{i v t}$ and $M_{i v(t-1)}$ are the current(1998) and past(1992) obtained credit, $X_{i v t}$ and $X_{i v(t-1)}$ are vector of present and past household, individual and village observables respectively, $\mu_{i v}$ is time-invariant individual characteristics, $\varphi_{v}$ is time-invariant village characteristics, $\omega$ and $\rho$ measures the effects of current and past credit respectively, $\theta, \sigma, \omega, \rho, \mu$ and $\varphi$ are parameters to be estimated and $u_{i v t}$ is the random error terms (Khandker 2005, 2008) (Note 8). By allowing for the lagged credit variable $M_{i v(t-1)}$ term, this model makes provision for the fact that individuals may borrow different loan amounts in the two periods. This is important in empowerment context as well since empowering women can be a long gradual process and thus needs to be observed over a few periods of time.

$$
\Delta Y_{i v t}=\theta \Delta X_{i v t}+\sigma \Delta X_{i v(t-1)}+\omega \Delta M_{i v t}+\rho \Delta M_{i v(t-1)}+\Delta u_{i v t}
$$

(Note 9)

Equation (3) has been estimated in this paper for the sample of eligible participants and ineligible women while for eligible non-participants, log of their cumulative borrowing has been used as proxy for credit access. It shows how unobservable characteristics have been removed by differencing their constant terms overtime.

\section{Results:}

Having justified the selection of individual and household level FE model, this paper now turns to explain and analyse the results obtained. 


\subsection{Analysing Determinants of the Demand for Credit:}

Equation 3 is estimated for eligible participants and ineligible women to determine factors that can influence demand for credit. Table 2 reports the fixed effect credit demand estimates of the eligible participants. The estimates indicate that greater landholding and higher expenditures incurred in distress increases demand for credit while more educated women have lower demand for credit.

Women who are land poor demand fewer loans than women who are resource rich. For every $10 \%$ increase in landholdings, demand for credit increases by $4.7 \%$. However, an increase in landholding may not necessarily indicate an improvement in wealth. If the type of landholding consists mostly of non-usable land, then a gain in landholding will have minimal effect on wealth. Hence, in spite of gain in land, there can be greater demand for credit. In addition, from summary statistics above, it seems to indicate the eligible participants are the very poor. Perhaps they feel more able to borrow loans and repay them with any gain in their landholding. The estimates also indicate women's maximum years of schooling in 1991 have a small negative impact on demand for credit overtime (although significant). This may indicate higher educated females are better positioned in the society to work and therefore may not require credit. The most significant effect is the estimate for the expenditure incurred in distress. Since 1998/99 data was collected soon after the devastating flood in 1998, many women in the panel sample experienced high costs due to the flood. As a result, this may have generated 'fresh' higher demand for credit, thus having a significant impact.

Having estimated the demand for credit by means of total cumulative borrowing, the lag of borrowing has been estimated in order to calculate the impacts on eligible participants.

For eligible non-participants, we do not observe any demand for micro credit since they self-selected themselves out of the programs. Therefore, utilising the data on loans that a few women have borrowed from informal sources and relatives, log of borrowing has been computed which will serve as a proxy for 'credit obtained' for the eligible non participants. This credit amount is treated in regression models in the same way as micro credit has been computed and treated in regression models for the eligible participants. Therefore, the outcome results that are obtained will be a comparison of impacts generated due to micro credit and impacts generated due to loans obtained from informal sources.

Table 3 reports on fixed effects estimates of outcomes of micro credit for eligible participants and table 4 reports on fixed effects estimates of outcomes of loans for eligible non-participants respectively.

\subsection{Labour Supply of Eligible and Ineligible Participants:}

From the above two tables, it can be seen that micro-credit obtained in both current period and in the past generates positive impacts in terms of number of days worked in both agricultural and non-agricultural sector with the effects being statistically significant for non-agricultural sector. On the other hand, loans borrowed from other sources do not generate any positive impacts on eligible non-participants in terms of labour supply. The positive impact on labour supply for eligible participants may come about due to more women obtaining loans for self-employment or working outside in order to keep up with loan repayments. Either ways, this allows the women to work in their self-chosen profession either in the household or outside their homes. This may indicate an improvement of their socioeconomic status both within and outside their homes that may bring about empowerment. However, it requires careful analysis of the results for the eligible non-participants. Only 18 of the 450 panel women borrowed from other sources. As such, measuring impacts of the loan borrowed on 450 women may under-report estimates if non participants are already working to their limits. However, given the large statistically significant effect on non-agriculture sector work and the granting of micro credit for small entrepreneurial purposes in rural Bangladesh, it can be concluded micro credit borrowers are able to work in their chosen profession with the credit they have obtained, thereby being more empowered relative to the non-participants.

\subsection{Non Land Asset Accumulation:}

Eligible participants seemed to exhibit higher accumulation of non-land assets with current borrowing at an increasing rate between the two surveys. A $10 \%$ increase in current borrowed money can increase non-land asset holdings by $28 \%$. However, the result is not very statistically significant. It needs to be checked what asset is being accumulated. Usually, women tend to accumulate low value goods such as utensils since women in rural Bangladesh are linked with kitchen or household tasks. Such accumulation may not necessarily lead to greater empowerment. However, the eligible participants in the dataset mostly acquired agricultural stock such as cows and poultry as non-land asset which enable them to trade poultry eggs or cow milk and also provide food for household members. This can lead to an empowering effect since they can generate income from such sources and benefit the household which in turn can improve their standing within the household. To the contrary, loans from other sources for non-participants have a positive significant impact on asset accumulation, although at a declining rate. 


\subsection{Family Planning:}

Family Planning has been measured as impact of borrowing on the number of additional births since 1992. The results indicate past credit (1992 credit) has a smaller and negligible positive impact on eligible participants while past loans have bigger and significant positive impact on number of additional births for eligible non-participants. On the other hand, current credit has a bigger positive impact on number of births for both eligible participants and non-participants. The results under family planning contradicts the assumption for empowerment: micro credit should enable participants to become more aware of family planning methods and also by encouraging self-employment, it should increase the productivity of women and increase the opportunity cost of staying home and bringing up the child. Moreover, through female group formation in micro credit, women become a part of social network, whereby they are more likely to gain information on sensitive issues by sharing their problems with other women. A naive conclusion could say more borrowing leads to higher income, which in turn can lead to higher number of births. However, it needs to be taken in to account that family planning methods are promoted by GoB and other NGOs in rural Bangladesh. In addition, there is an increase of $36 \%$ in contraceptive use among the panel women. A more reliable indicator would have been measuring the likelihood of using contraceptives among the borrowers from participating in microcredit programmes.

For the next two indicators, a household level fixed effects model has been implied since the indicators involve household level decision.

\subsection{Children's Education}

Borrowing credit from microfinance has a significant positive impact on the number of children from the panel women's households who are enrolled in school. The estimates of eligible non-participants are slightly lower than the estimates of eligible participants and are not significant. The large similarity in number of children sent to school can be explained by a few factors. Government incentives such as the previous 'Food for Thought' and the present 'Cash Incentives' for sending children to school may manipulate household's decision to send their children to school. Furthermore, as the economy develops, people start valuing education more. Hence, an increasing number of households are sending their children to school.

The positive estimates indicate some women started sendings their children to school after receiving loans. This may also indicate an improvement of bargaining power of women within the household. Often, extended families tend to live together in rural villages. Therefore, if women in such households borrow and send their children to school, not only does this indicate women taking responsibility towards sharing the burden of household cost, but are also managing to persuade large number of family members to send their children to school, thereby indicating an improvement of bargaining power within the household.

\subsection{Household Total Expenditure (Includes Both Food And Non-Food Items)}

For the eligible participants, there is a positive but insignificant effect of current and past credit on total household expenditure (Note 10). Separating expenditure in terms of food and non-food, it can be seen that on one hand expenditure on food has fallen and on the other hand, expenditure on non-food items has risen. Studying the items that the eligible participants bought, it was revealed a lot of women acquired utensils and furniture (non-land asset since they are cheaper than land). However, the category that contributed most towards non-food expenditure was clothes for adults. If these clothes were for the women themselves, clearly that would indicate empowerment since women were able to spend the money for their own wants. Nevertheless, spending for household members can help the woman gain acknowledgement from members and the valuable support can also help to promote her socioeconomic status.

For the eligible non participants, it can be seen that there are significant negative impacts of borrowing on total household expenditure as well as total food expenditure and non-food expenditure. This can indicate that these women do not spend the loans on household outcomes such as food and non-food expenditure. They spend the money on land accumulation since the summary statistics indicated these women had higher landholdings, both in acres and in values. The results showed negative impacts on employment from borrowing loans. If these results are true in practice, then one can conclude eligible participants are likely to be empowered by borrowing through microfinance than eligible non-participants: this is represented by higher labour market participation, greater accumulation of non-land assets, more children sent to school and increase in household total expenditure (Note 11).

All Panel Women estimates: The above outcomes were estimated for all panel sample women to determine how much micro-credit affects other non-participants and ineligible women (Note 12). It needs to be noted that 49 of the individuals borrowed funds from other sources. Since this represents about $3.5 \%$ of all panel women, the paper has ruled out any impacts arising or being influenced due to sources of credit other than microfinance. 
Table 5 reports results obtained for all panel sample women. In the individual level outcomes, current credit had no significant impact in the labour market while it had a high significance on asset accumulation. This may be due to women being restricted to work outside homes. On average household expenditure and food and non-food expenditure has gone up from credit borrowed. However, children's schooling has been negatively affected by all forms of credit on these women. It is hard to explain this finding but one possibility could be if children are unable to go to school due to the floods in 1998.

In explaining all panel women's outcomes, a few factors need to be borne in mind. One is economic prosperity where the women reside. That may influence outcomes on non-participants and ineligible women as well as on participants, but the causality may not flow from women participating in credit programs to women who did not/could not. Another issue could be individual characteristics of women, such as marital status and geographical location. If they change for many women, results on all women may fail to capture impacts of microfinance. Overall, the panel results conclude positive impacts overtime on asset accumulation (significant), labour market participation (non-significant) and household expenditure of all panel women (highly significant).

\section{Conclusion:}

It must be acknowledged that empowerment is a very broad concept to define and measure. Yet this paper attempted to derive robust outcomes of participating in microfinance by using a panel data survey and implying a fixed effects model. After that, the results were analyzed bearing in mind the societal and household norms that women in rural Bangladesh experience. The paper compared the outcomes of eligible participants to the outcomes of credit borrowed from other sources by eligible non-participants. By doing so, it was possible to measure the benefits of participating in a credit program. These benefits were analyzed further in terms of whether they empowered women. As such, the link between the robust results and possibility of an underlying empowerment factor has been established. The results concluded participating women have better significant results in terms of both individual and household level outcomes than eligible non-participants.

However, in any further studies of women empowerment, it is important to measure any disempowerment effect happening within the household or even worse, at social level. As more of the microfinance institutions are channeling the credit through women, men are relying upon women for obtaining loans (Khandker 2008). Given that Bangladesh is a highly male-dominated society, these women may ultimately give up their loans to their husbands, which may completely nullify all impacts that have been associated with empowerment. Indeed, this case is reported by Armendáriz and Groome (2008) whereby women surrender $40 \%$ of the investment decisions involving loans to their husbands. Hence, credit fungibility may be negatively correlated with empowerment. As Armendáriz and Groome (2008) mentioned in their paper, higher income generated through microfinance can empower women, but the lack of credit availability and the rising success of women may bring in friction within the household. This is the disempowering effect of women.

Without keeping this in mind, one can conclude a woman in rural Bangladesh who is financially self-dependent is empowered, while at home she experiences domestic violence by her husband. One way to deal with the problem of disempowerment is by inviting the husbands to join the women's groups (Allen et al, 2010). Any policy that is implemented for eliminating the disempowerment effect of women needs to restore the trust between the credit participant and her household members involving money matters. Without trust, frictions will always prevail. Moreover, along with the change in mentality of people in understanding the role of a woman, societal institutions need to change as well in order to incorporate greater economic freedom of women. If these external factors remain time-invariant, the micro credit can only generate temporary empowerment effects on women in terms of income generation and asset accumulation. Overtime, these benefits will nullify as more women achieve the same outcome leaving no room for marginal gains from credit program participation.

\section{References}

Allen, T., Armendáriz, B., Karlanz, D., Mullainathanx, S., (2010). Inviting Husbands in Women Only Solidarity Groups: Evidence from Southern Mexico.

Armendáriz, B., Morduch, J., (2010). The Economics of Microfinance, Cambridge MA, MIT Press

Goetze, Marie, A., and Sengupta, R. (1996). Who takes the credit? Gender, power, and control over loan use in rural credit programs in Bangladesh, World Development 24(1): 45-63. doi:10.1016/0305-750X(95)00124-U, http://dx.doi.org/10.1016/0305-750X(95)00124-U

Hashemi, M., Schuler, S. and Riley, A. (1996).Rural Credit Programs And Women's Empowerment In Bangladesh. World Development 24(4):635-53. doi:10.1016/0305-750X(95)00159-A, http://dx.doi.org/10.1016/0305-750X(95)00159-A 
Khandker, S., Koolwal, G., Sinha,N.(2008). Benefits of Improving Young Women's Labour Market Opportunities: Evidence from Group-based Credit Programs in Rural Bangladesh, World Bank Development Report.

Khandker, S. (2005). Microfinance and Poverty: Evidence using panel data from Bangladesh, World bank Economic Review, Vol 19, Issue 2, Pages 263-286. doi:10.1093/wber/lhi008, http://dx.doi.org/10.1093/wber/lhi008

Khandker, S.(1998). Fighting Poverty With Micro Credit: Experience In Bangladesh, Journal of Political Economy 106(5):958-96.

Khandker, S., Baqui, K., Kahn, Z. (1995). Grameen Bank: Performance \& Sustainability”, World Bank Discussion Paper 306, Washington, D.C

Morduch, J. (1999). The Role of Subsidies in Microfinance: Evidence From The Grameen Bank, Journal of Development Economics, Elsevier, vol. 60(1), pages 229-248.

Pitt, M., Khandker, S. (1998). Impact of Group-Based credit programs on Poor Households in Bangladesh: Does the Gender of Participants Matter? Journal of Political Economics: 958-96. doi:10.1086/250037, http://dx.doi.org/10.1086/250037

Pitt, Mark M., Khandker, Shahidur R. Cartwright \& Jennifer. Does Micro-Credit Empower Women: Evidence From Bangladesh, Volume 1, Policy, Research Working Paper Series; No. WPS 2998.

Pitt, M. (1999). Reply to Jonathan Morduch's 'Does Microfinance Really Help the Poor? New Evidence from Flagship Programs in Bangladesh. Brown University, Department of Economics

Wooldridge, G. (2006). Introductory Econometrics, A Modern Approach, South-Western Educational Publishing

Wooldridge, G. (2002). Econometric Analysis of Cross Section and Panel Data, The MIT Press

Zaman, H. (1999). Assessing the Poverty and Vulnerability Impact of Micro-Credit in Bangladesh: A case study of BRAC, World Bank Policy Research Working Paper 1798.

\section{Notes}

Note 1. Eligibility for program participation is determined by the landholding of the households. Any households having less than 0.5 acres (50 decimals) of land are eligible to participate in the credit programs ${ }^{1}$ (target households) and households with landholdings of more than 0.5 acres are ineligible to participate (non-target households). Among the eligible households, some select to participate (eligible participants) while some select to not participate in the programs (eligible non-participants).

Note 2 As the data is not tailored to examining women empowerment, it has been necessary to use the data in measuring impacts that serve as proxies of women empowerment rather than as an absolute measurement of women empowerment.

Note 3. It is reasonable to assume that micro-credit participation will have welfare effects after some period of time.

Note 4Moreover, there were only a few households from which multiple women were observed. Hence, household-level fixed-effects would not have been appropriate since controlling for household factors may not necessarily control the individual level heterogeneity across females.

Note 5. Although there can be inheritance of assets. For example, if the husband or father of the woman dies, she may inherit his assets; another instance could arise when a woman gets married. She can be gifted with assets. However, asset accumulation figures used in the analysis were mostly purchased, either before 1992 or since 1992.

Note 6. A better indicator of children's education would be the enrolment rate since this would measure the proportion of children who are sent to school and can indicate how much households value children's education. However, I was unable to conduct a research using enrolment rates in the fixed effects model because the estimates of parameters on variables of interest were being dropped. Number of children enrolled in school has been used as a proxy for 'children's school enrolment'.

Note 7. Attrition bias refers to the loss in number of households who could not be traced in the $2^{\text {nd }}$ survey. Only $7 \%$ of the households (Khandker 2005) interviewed in $1^{\text {st }}$ survey could not be traced in the $2^{\text {nd }}$ survey. Hence, bias due to attrition is likely to be small.

Note 8. Under cross-section data, it was the correlation between the error terms $\varepsilon_{i v t}$ and $u_{i v t}$ that resulted in endgeneity between explanatory variables and the error terms.

Note 9. Obtained by differencing the average of equation (2) for each individual from equation (2) 
Note 10. Total household expenditure has been computed by summing the total annual food expenditure and the total annual non-food expenditure.

Note 11. However, children's schooling and household expenditure are household level decisions and therefore this paper cannot rule out the possibility of expenditure and children's schooling decisions taken by the male members of the household.

Note 12.This does not necessarily measure spill-over benefits. This model only attempts to shed some light on the effect of micro credit on an average woman.

Note 13. Model had been run under both fixed effects and random effects to check if the individual unobservable were correlated with the observable characteristics. A Durbin-Wu Hausman test was run in which the test results confirmed the use of fixed effects model.

Note 14. Robust standard errors have been obtained in all models and wherever needed, Wooldridge serial correlation test was conducted to check if there were any autocorrelations or panel level heteroskedasticity.

Table 1. Distribution of Households by Eligibility (Landholding criteria)

\begin{tabular}{|c|c|c|c|c|}
\hline \multirow{2}{*}{ Households by eligibility criteria } & \multicolumn{2}{|c|}{$\mathbf{1 9 9 1 / 9 2}$} & \multicolumn{2}{|c|}{$\mathbf{1 9 9 8 / 9 9}$} \\
\cline { 2 - 5 } & $\begin{array}{c}\text { Number of } \\
\text { households }\end{array}$ & $\begin{array}{c}\text { \% of } 1633 \text { panel } \\
\text { households }\end{array}$ & $\begin{array}{c}\text { Number of } \\
\text { households }\end{array}$ & $\begin{array}{c}\text { of } 1633 \text { panel } \\
\text { households }\end{array}$ \\
\hline Eligible Households & 379 & $23.2 \%$ & 1093 & $66.9 \%$ \\
\hline Eligible Non-participating Households & 1007 & $61.6 \%$ & 336 & $20.6 \%$ \\
\hline Ineligible Households & 247 & $15.1 \%$ & 194 & $11.9 \%$ \\
\hline Total & 1633 & & 1633 & \\
\hline
\end{tabular}

Source: Bangladesh Institute of Development Studies-World Bank's Credit Programs for the Poor 1991/92 survey and its follow-up survey in $1998 / 99$

Table 2. Fixed Effects Estimates of determinants of demand for credit

\begin{tabular}{|c|c|c|}
\hline \multirow[t]{2}{*}{ Explanatory variables } & \multicolumn{2}{|c|}{$\begin{array}{c}\text { Individual-level fixed effects } \\
\text { Panel data } \\
\end{array}$} \\
\hline & $\begin{array}{l}\text { Demand for micro credit of eligible } \\
\text { participants }\end{array}$ & $\begin{array}{c}\text { Demand for village credit of all women } \\
\text { households }\end{array}$ \\
\hline Log of landholding in acres & $0.4762 *$ & $\begin{array}{c}0.5204^{*} \\
(1.02)\end{array}$ \\
\hline $\begin{array}{c}\text { Maximum years of schooling in 1991/92 } \\
\text { * year }\end{array}$ & $-0.000078^{*}$ & $\begin{array}{c}-0.0266^{*} \\
(-0.60) \\
\end{array}$ \\
\hline $\begin{array}{l}\text { Log of total expenditure in the past } 12 \\
\text { months }\end{array}$ & 0.1059 & $\begin{array}{c}0.1105^{*} \\
(1.27)\end{array}$ \\
\hline $\begin{array}{l}\text { Log of expenditure incurred in distress in } \\
1998 / 99\end{array}$ & $0.1073^{*}$ & $\begin{array}{c}0.2290^{*} \\
(1.35) \\
\end{array}$ \\
\hline $\begin{array}{l}\text { Log of cost of consultation due to injury } \\
\text { in } 1991 / 92\end{array}$ & 0.4124 & $\begin{array}{c}0.0127^{*} \\
(0.27)\end{array}$ \\
\hline F-statistics & 11.07 & 2.81 \\
\hline Number of observations & 735 & 1382 \\
\hline
\end{tabular}

Remarks (1) Regression also includes year, age, marital status, if house had electricity, distance of nearest bank from house, distance of nearest hat from village*year and price of daily necessities to control for individual characteristics, household standards and village characteristics (Note 13) (Note 14) (2) * t-statistic is significant at $10 \%$ level or better 
Table 3. Fixed Effects linear estimates of micro finance on eligible participants

\begin{tabular}{|c|c|c|c|c|c|c|c|c|}
\hline $\begin{array}{l}\text { Explanatory } \\
\text { variables }\end{array}$ & $\begin{array}{l}\text { Number } \\
\text { of days } \\
\text { worked in } \\
\text { others' } \\
\text { farms in } \\
\text { previous } \\
\text { month }\end{array}$ & $\begin{array}{l}\text { Number of } \\
\text { days worked in } \\
\text { self-employed } \\
\text { activities in } \\
\text { previous month }\end{array}$ & $\begin{array}{l}\text { Log of } \\
\text { non-land } \\
\text { assets' } \\
\text { value } \\
\text { (Taka) }\end{array}$ & $\begin{array}{l}\text { Number of } \\
\text { children in } \\
\text { household } \\
\text { enrolled in } \\
\text { school }^{i}\end{array}$ & $\begin{array}{l}\text { Log of } \\
\text { household } \\
\text { total } \\
\text { expenditure } \\
\text { per annum } \\
\text { (Taka) }\end{array}$ & $\begin{array}{l}\text { Log of } \\
\text { household } \\
\text { total food } \\
\text { expenditure } \\
\text { per annum } \\
\text { (Taka) }\end{array}$ & $\begin{array}{l}\text { Log of } \\
\text { household } \\
\text { total } \\
\text { non-food } \\
\text { expenditure } \\
\text { per annum } \\
\text { (Taka) }\end{array}$ & $\begin{array}{l}\text { Number of } \\
\text { additional } \\
\text { births } \\
1992-1998\end{array}$ \\
\hline $\begin{array}{l}\text { Log of } \\
\text { current credit } \\
(1998)\end{array}$ & $\begin{array}{l}0.0059 \\
(0.70)\end{array}$ & $\begin{array}{l}0.1992 * \\
(1.61)\end{array}$ & $\begin{array}{l}2.7929 \\
(0.74)\end{array}$ & $\begin{array}{l}0.0265^{*} \\
(1.80)\end{array}$ & $\begin{array}{l}0.0034 \\
(0.28)\end{array}$ & $\begin{array}{l}-0.0014 \\
(-0.10)\end{array}$ & $\begin{array}{l}0.0179 \\
(0.92)\end{array}$ & $\begin{array}{l}0.0764 \\
(1.11)\end{array}$ \\
\hline $\begin{array}{l}\text { Log of past } \\
\text { credit } \\
\text { (pre-1998) }\end{array}$ & $\begin{array}{l}0.0089 \\
(0.43)\end{array}$ & $\begin{array}{l}0.5401 * * * \\
(2.76)\end{array}$ & $\begin{array}{l}-0.0025^{*} \\
(-0.01)\end{array}$ & $\begin{array}{l}0.0284^{*} \\
(1.74)\end{array}$ & $\begin{array}{l}0.0187 \\
(1.25)\end{array}$ & $\begin{array}{l}0.0201 \\
(1.23)\end{array}$ & $\begin{array}{l}0.0218 \\
(0.90)\end{array}$ & $\begin{array}{l}0.0002 \\
(0.19)\end{array}$ \\
\hline R-squared & 0.805 & 0.474 & 0.685 & 0.052 & 0.745 & 0.692 & 0.806 & 0.236 \\
\hline Prob $>F$ & 0.0000 & 0.0000 & 0.0044 & 0.0514 & 0.0000 & 0.0000 & 0.0000 & 0.0000 \\
\hline
\end{tabular}

Table 4. Fixed Effects Linear Estimates of credit from other sources on eligible non-participants

\begin{tabular}{|c|c|c|c|c|c|c|c|c|}
\hline $\begin{array}{l}\text { Explanatory } \\
\text { variables }\end{array}$ & $\begin{array}{l}\text { Number } \\
\text { of days } \\
\text { worked in } \\
\text { others' } \\
\text { farms in } \\
\text { previous } \\
\text { month } \\
\end{array}$ & $\begin{array}{l}\text { Number of } \\
\text { days worked in } \\
\text { self-employed } \\
\text { activities in } \\
\text { previous month }\end{array}$ & $\begin{array}{l}\text { Log of } \\
\text { non-land } \\
\text { assets' } \\
\text { value } \\
\text { (Taka) }\end{array}$ & $\begin{array}{l}\text { Number of } \\
\text { children in } \\
\text { household } \\
\text { enrolled in } \\
\text { school }^{i}\end{array}$ & $\begin{array}{l}\text { Log of } \\
\text { household } \\
\text { total } \\
\text { expenditure } \\
\text { per annum } \\
\text { (Taka) }\end{array}$ & $\begin{array}{l}\text { Log of } \\
\text { household } \\
\text { total food } \\
\text { expenditure } \\
\text { per annum } \\
\text { (Taka) }\end{array}$ & $\begin{array}{l}\text { Log of } \\
\text { household } \\
\text { total } \\
\text { non-food } \\
\text { expenditure } \\
\text { per annum } \\
\text { (Taka) } \\
\end{array}$ & $\begin{array}{l}\text { Number of } \\
\text { additional } \\
\text { births } \\
1992-1998\end{array}$ \\
\hline $\begin{array}{l}\text { Log of } \\
\text { current credit } \\
(1998)\end{array}$ & $\begin{array}{l}-0.0009 \\
(-0.10)\end{array}$ & $\begin{array}{l}-0.0034 \\
(-0.25)\end{array}$ & $\begin{array}{l}0.3149 * \\
(1.86)\end{array}$ & $\begin{array}{l}0.0134 \\
(0.61)\end{array}$ & $\begin{array}{l}-0.0309^{*} \\
(-1.61)\end{array}$ & $\begin{array}{l}-0.0422 \\
(-1.54)\end{array}$ & $\begin{array}{l}-0.0121 \\
(-0.37)\end{array}$ & $\begin{array}{l}0.3019 \\
(1.17)\end{array}$ \\
\hline $\begin{array}{l}\text { Log of past } \\
\text { credit } \\
\text { (pre-1998) }\end{array}$ & $\begin{array}{l}-0.2284 \\
(-1.10)\end{array}$ & $\begin{array}{l}-0.0087 \\
(-0.37)\end{array}$ & $\begin{array}{l}0.4811^{*} \\
(2.02)\end{array}$ & $\begin{array}{l}0.0343 \\
(0.75)\end{array}$ & $\begin{array}{l}-0.0761^{* * *} \\
(.2 .64)\end{array}$ & $\begin{array}{l}-0.0863^{* *} \\
(-2.39)\end{array}$ & $\begin{array}{l}-0.0521 \\
(-1.11)\end{array}$ & $\begin{array}{l}0.0699 * \\
(1.60)\end{array}$ \\
\hline R-squared & 0.684 & 0.927 & 0.208 & 0.104 & 0.749 & 0.692 & 0.856 & 0.225 \\
\hline Prob $>F$ & 0.0000 & 0.0000 & 0.0000 & 0.1992 & 0.0000 & 0.0000 & 0.0000 & 0.0000 \\
\hline
\end{tabular}

Remarks (1): Wherever applicable, the above regressions were done including either all or a combination of the following variables: year, age, marital status, maximum education of female in 1991/92*year, log of total expenditure past year, log of total cost incurred in distress, log of cost incurred in consultation, distance of nearest haat from village*year, if the household has electricity, wage received from agriculture, wage from non-agricultural sector, distance to school*year and price variables in village to take account of village level time varying changes.

(2) $\mathrm{t}$ statistics are in parenthesis; * t-statistic significant at $10 \%$ level or better; $* *$ t-statistic significant at $5 \%$ level or better; $* * * t$-statistic significant at $1 \%$ level or better 
Table 5. Fixed effects linear estimates of micro finance and loans from other sources on all women

\begin{tabular}{|c|c|c|c|c|c|c|c|}
\hline $\begin{array}{l}\text { Explanatory } \\
\text { variables }\end{array}$ & 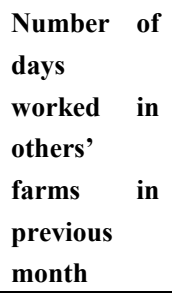 & $\begin{array}{l}\text { Number of days } \\
\text { worked in } \\
\text { self-employed } \\
\text { activities in } \\
\text { previous month }\end{array}$ & $\begin{array}{l}\text { Log of } \\
\text { non-land } \\
\text { assets' } \\
\text { value } \\
\text { (Taka) }\end{array}$ & $\begin{array}{l}\text { Number of } \\
\text { children in } \\
\text { household } \\
\text { enrolled in } \\
\text { school }\end{array}$ & $\begin{array}{l}\text { Log of } \\
\text { household } \\
\text { total } \\
\text { expenditure } \\
\text { per annum } \\
\text { (Taka) }\end{array}$ & $\begin{array}{l}\text { Log of } \\
\text { household } \\
\text { total food } \\
\text { expenditure } \\
\text { per annum } \\
\text { (Taka) }\end{array}$ & $\begin{array}{l}\text { Log of } \\
\text { household total } \\
\text { non-food } \\
\text { expenditure } \\
\text { per annum } \\
\text { (Taka) }\end{array}$ \\
\hline $\begin{array}{l}\text { Log of current } \\
\text { credit (1998) }\end{array}$ & $\begin{array}{l}0.2317 \\
(0.89)\end{array}$ & $\begin{array}{l}0.8687 \\
(1.11)\end{array}$ & $\begin{array}{l}9.4401 * * * \\
(21.88)\end{array}$ & $\begin{array}{l}-1.1628 \\
(-1.51)\end{array}$ & $\begin{array}{l}0.9973 * * * \\
(9.99)\end{array}$ & $\begin{array}{l}0.2741 * * * \\
(2.98)\end{array}$ & $\begin{array}{l}1.1041 * * * \\
(9.93)\end{array}$ \\
\hline $\begin{array}{l}\text { Log of past } \\
\text { credit } \\
\text { (pre-1998) }\end{array}$ & $\begin{array}{l}-0.1162 * \\
(-1.84)\end{array}$ & $\begin{array}{l}-0.1466 \\
(-0.62)\end{array}$ & $\begin{array}{l}-0.1123 \\
(-0.70)\end{array}$ & $\begin{array}{l}-0.6438 \\
(-0.60)\end{array}$ & $\begin{array}{l}-0.0524 \\
(-0.98)\end{array}$ & $\begin{array}{l}0.1441 * * * \\
(2.78)\end{array}$ & $\begin{array}{l}-0.0737 \\
(-1.29)\end{array}$ \\
\hline R-squared & 0.819 & 0.735 & 0.630 & 0.636 & 0.842 & 0.701 & 0.825 \\
\hline Prob $>F$ & 0.0000 & 0.0000 & 0.0000 & 0.0000 & 0.0000 & 0.0000 & 0.0000 \\
\hline
\end{tabular}

Remarks (1): Wherever applicable, the above regressions were done including either all or a combination of the following variables: year, age, marital status, maximum education of female in 1991/92*year, log of total expenditure past year, log of total cost incurred in distress, log of cost incurred in consultation, distance of nearest haat from village*year, if the household has electricity, wage received from agriculture, wage from non-agricultural sector, distance to school*year and price variables in village to take account of village level time varying changes.

(2) $\mathrm{t}$ statistics are in parenthesis; * t-statistic significant at $10 \%$ level or better; ** t-statistic significant at $5 \%$ level or better; $* * * t$ tstatistic significant at $1 \%$ level or better

(3) Due to impact of microfinance on family planning being ambiguous for participants and non-participants, possibility of external policies affecting family planning decision of all families and availability of limited data on number of additional births for the ineligible women, it is difficult to derive results on number of additional births 1992-1998 and report the results as benefits of microfinance. Therefore, this article has ruled out examining family planning impact on all women. 